\title{
Caring ability of urban and rural family caregivers: association with overburden, stress and coping*
}

\author{
Habilidade de cuidado de cuidadores familiares urbanos e \\ rurais: relação com a sobrecarga, estresse e coping \\ Habilidad de cuidadores familiares urbanos y rurales: relación con \\ la sobrecarga, el estrés y el afrontamiento (coping)
}

How to cite this article:

Siqueira FD, Girardon-Perlini NMO, Andolhe R, Zanini RR, Santos EB, Dapper SN. Caring ability of urban and rural family caregivers: association with overburden, stress and coping. Rev Esc Enferm USP. 2021;55:e03672. doi: https://doi.org/10.1590/S1980-220X2019019103672

\author{
Fernanda Duarte Siqueira ${ }^{1}$ \\ Nara Marilene Oliveira Girardon- \\ Perlini ${ }^{1}$ \\ D Rafaela Andolhe 1 \\ Roselaine Ruviaro Zanini² \\ Evelyn Boeck dos Santos ${ }^{1}$ \\ Steffani Nikoli Dapper ${ }^{3}$ \\ * Extracted from the dissertation: "Habilidade \\ de cuidado, sobrecarga, estresse e coping \\ de cuidadores familiares urbanos e rurais \\ de pacientes em tratamento oncológico", \\ Programa de Pós-Graduação em Enfermagem, \\ Universidade Federal de Santa Maria, 2019. \\ ${ }^{1}$ Universidade Federal de Santa Maria, \\ Programa de Pós-Graduação em \\ Enfermagem, Santa Maria, RS, Brazil \\ 2 Universidade Federal de Santa Maria, \\ Programa de Pós-Graduação em Engenharia \\ de Produção, Santa Maria, RS, Brazil. \\ ${ }^{3}$ Universidade Federal de Santa Maria, \\ Programa de Pós-Graduação em \\ Administração, Santa Maria, RS, Brazil.
}

\begin{abstract}
Objective: To correlate caring ability with overburden, stress and coping of urban and rural family caregivers of patients undergoing cancer treatment. Method: Crosssectional study, carried out in a referral hospital for cancer treatment, with urban and rural caregivers who responded the following instruments: questionnaire of sociodemographic characterization of the caregiver and the care provided, Perceived Stress scale, Burden Interview scale and Brief COPE. Pearson's correlation test was used for statistical analysis, with a significance level $\leq 5 \%$. Results: A total of 163 urban caregivers and 59 rural caregivers participated in the study. Between the caring ability and stress, a negative and moderate correlation was found in rural caregivers. In the relationship between the caring ability and the overburden, there was a statistically significant correlation in urban caregivers in the interpersonal relationship and perception of self-efficacy factor. Between coping and the caring ability, a positive and moderate correlation was identified in coping focused on the problem in the knowledge dimension in urban caregivers. Conclusion: Urban caregivers had greater intensity of overburden and coping focused on the problem in relation to the caring ability.
\end{abstract}

\section{DESCRIPTORS}

Caregivers; Patients; Neoplasms; Urban Population; Rural Population; Oncology Nursing. 


\section{INTRODUCTION}

Currently, cancer is one of the chronic non-communicable diseases with the greatest economic impact on health services, both globally and nationally ${ }^{(1)}$. Thus, the particularities of the illness can cause irreversible pathological changes that can compromise people's ability to perform daily activities, requiring permanent care, both in the hospital and at home ${ }^{(2)}$. So, in a situation of incapacitating chronic illness, the demands for care can increase, generally requiring that a family member assume this responsibility as a caregiver ${ }^{(3)}$. The assumption of this role occurs gradually or suddenly, for which the caregiver may not be prepared, requiring the development of caring abilities ${ }^{(4)}$.

Thus, the ability to care is understood as a potential that a person has to assume the role of caregiver of a relative or significant person who has an incapacitating illness ${ }^{(5)}$. Under such considerations, this ability includes cognitive, instrumental and attitudinal dimensions that can be identified and measured according to indicators of knowledge, courage and patience $^{(5)}$. The performance of caregiver functions without the balance between the caring ability and its dimensions, can lead to physical, emotional and social issues and, consequently, raise the perception of overburden and stress ${ }^{(6)}$. Moreover, the need to use certain coping strategies that favor dealing with the illness and care process stands out ${ }^{(7)}$.

Regarding living in the urban and rural context, caregivers face challenges in their responsibility to care, which may be related to their particularities and experiences in different ways in each environment ${ }^{(8)}$. Therefore, in order to know the possible differences and the performance of caregivers in the care function, comparing the urban and rural context, one sought, through a narrative review in the National Library of Medicine - PubMed and in Latin American and Caribbean Health Sciences (LILACS), and in the Scientific Electronic Library Online (SciELO) databases, to identify publications on this topic. As a result, it was found that comparative researches, among these scenarios, are still incipient and concentrated in the international context ${ }^{(8-11)}$, indicating a gap in the production of Brazilian studies and the need to develop investigations aimed at deepening knowledge in this topic related to factors that may interfere with being a caregiver in these scenarios.

Thus, the following question emerges: how do the caring ability and the overburden, stress and coping of urban and rural family caregivers of patients undergoing cancer treatment correlate? So, the study aims to correlate the caring ability with the overburden, stress and coping of urban and rural family caregivers of patients undergoing cancer treatment.

\section{METHOD}

\section{TYPE OF STUDY}

This is a cross-sectional study.

\section{SCENARIO}

It was carried out in the chemotherapy and radiotherapy sectors of a reference institution for cancer treatment in Rio Grande do Sul state.
The study population consisted of urban and rural family caregivers of patients undergoing cancer treatment.

\section{SeLECTION CRITERIA}

The selection of caregivers occurred based on the identification of patients over 18 years old, undergoing cancer treatment in the chemotherapy and radiotherapy sectors, who had some kind of dependence to perform daily activities at home, assessed by the Barthel Index ${ }^{(12)}$. The caregivers responsible for the care provided at home to the dependent patient were selected, and they may be a family member, friend, neighbor or other person considered significant aged 18 years old or more, regardless of the time in care. In situations where there was more than one caregiver, the patient was asked to indicate the caregiver who provided the longest care and was considered the main one.

\section{SAMPLE DEFINITION}

Nonprobability sampling technique was used. Therefore, a total of 264 dependent patients were seen at the service during the data collection period. When contacting the caregivers, thirty of them were not the main ones, five had difficulties in understanding and interpreting the questions of the data collection instruments, two were under 18 years old and five did not accept to participate in the research. Thus, the sample consisted of a total of 222 family caregivers, representing $84.09 \%$ of the population of dependent patients undergoing cancer treatment during this study. The final sample was divided into two groups, according to where the caregivers live: urban area $(n=163)$ and rural area $(n=59)$.

\section{Data collection}

Data collection was carried out from April 2017 to May 2018, through the application of a questionnaire of sociodemographic characterization of the caregiver and the care provided, the Caring Ability Inventory (CAI), the Burden Interview Scale, the Perceived Stress Scale (PSS) and the brief COPE.

\section{SOCIODEMOGRAPHIC CHARACTERIZATION QUESTIONNAIRE}

It contains the variables: gender, age, educational level, marital status, family income, time and period of care, assistance from other people and who lives with them.

\section{CARING Ability InVEntory (CAI)}

CAI was created in $1990^{(5)}$ with the objective of assessing people's abilities based on their own perception to provide proper care, paying attention to instrumental and cognitive aspects. It was validated and translated into Brazilian Portuguese in $2016^{(13)}$ and the reliability and validity were evaluated by Cronbach's Alpha, obtaining a value of 0.78 and the Correlation Coefficient with a score of $0.76^{(13)}$. In this study, the internal consistency obtained was 0.68 in the total CAI. It consists of 37 items, which are divided into three dimensions: knowledge, courage and patience, with 14,13 and 10 items, respectively. Responses are organized on a Likert scale, ranging from 1 to 5,1 referring to "strongly disagree" 
and 5 "strongly agree". The responses to the items are added, generating a total score and one for each subscale ${ }^{(5)}$.

\section{Burden INTERVIEW SCALE}

The scale was translated and validated for Brazil in 2002 and obtained a Cronbach's Alpha of $0.87^{(14)}$. It consists of a total of 22 items, where each item is scored from zero to four. When adding the score, a global score is obtained, which can vary from zero to 88 . The higher the score, the greater the perception of overburden, being classified as: <20: absence of burden; 21-40: mild to moderate burden; 41-60 moderate to severe burden; >60 intense burden ${ }^{(15)}$. In addition, the scale has a multidimensional construct that allows the assessment of objective and subjective overburden, consisting of four factors: impact on care provision (ICP) and interpersonal relationship (IR), which are directed towards objective overburden; expectation regarding care (ERC) and perception of self-efficacy (PS), which are factors that lead to subjective overburden ${ }^{(16)}$. It is noteworthy that this scale has already been translated into several languages, being used in many countries with caregivers of dependent people in different age groups and situations of illness ${ }^{(13-16)}$.

\section{Perceived Stress Scale (PSS)}

A scale originally developed in $1983^{(17)}$ and validated for the Portuguese language in 2007. Internal consistency was verified by obtaining a Cronbach's Alpha of $0.62^{(18)}$. It is a scale composed of 14 items, seven positives and seven negatives, and each item on the scale is scored from zero to five. The questions with a positive connotation have their scores reversed, and the other questions are negative and must be added directly. Thus, the higher the score, the greater the perception of stress $^{(18)}$.

\section{COPE-BRIEF}

Instrument translated and validated for the Brazilian population in 2012 and had a Cronbach's Alpha of 0.84(19). It contains a total of 28 items evaluated by a Likert scale, which varies from one to four, in which $1=\mathrm{I}$ have not done it and $4=\mathrm{I}$ have done it a lot, allowing the interviewees to report what they usually do regarding the stressor. The scores are added, and the higher the score obtained, the greater the use of a certain coping strategy. The result of the scale points to a profile based on the more or less used subscales. The type of coping used can be classified as focused on the problem or focused on emotion, which can be subdivided into adaptive or maladaptive ${ }^{(19)}$.

\section{Data ANAlysis}

For statistical analysis, the data were organized and typed concurrently with the data collection period, in an electronic spreadsheet, Excel for Windows, by independent double data entry. After checking for inconsistencies, the information was analyzed electronically with the Statistical Package for Social Sciences (SPSS) version 23.0. The data obtained were grouped according to where the caregivers live and the sociodemographic variables were all measured categorically and presented by the distribution of absolute and relative frequencies. The normality of the groups was tested using the Lilliefors test. The internal consistency of the instruments used was assessed by Cronbach's Alpha. The association between the caring ability with the overburden, stress and coping was assessed by Pearson's Correlation Coefficient, at a significance level $\leq 5 \%$, given the adherence to data normality. For the analysis of the linear correlation forces between the measures, one used a classification that determines that the correlation values less than 0.30 indicate weak correlation and, even when statistically significant, do not have clinical relevance; values between 0.30 and 0.50 indicate a moderate correlation, and above 0.50 , a strong correlation ${ }^{(20)}$.

\section{ETHICAL ASPECTS}

The development of the research respected the ethical precepts that govern studies involving human beings of Resolution no. 466/2012, of the National Health Council and was approved by the Research Ethics Committee, protocol 1.977.316, from 2017. All participants signed the Informed Consent Form (ICF).

\section{RESULTS}

Regarding internal consistency, the instruments used presented the following values: Caring ability - total CAI-BR (0.68); Knowledge (0.63); Courage (0.67) and Patience (0.65); Overburden (0.83); Perceived stress (0.87) and COPE-Brief (0.72).

As for the characterization of the participants, there was a similarity in the comparison of frequencies in the analyzed variables, in which most caregivers were female (urban: $n=133 ; 81.60 \%$; rural: $n=43 ; 72.88 \%$ ), aged 48 to 76 years old (urban: $n=96 ; 58.90 \%$; rural: $n=38 ; 64.41 \%$ ), with a partner (urban: $n=124 ; 76.07 \%$; rural: $n=48 ; 81.36 \%$ ), with a family income up to three minimum wages (urban: $\mathrm{n}=105 ; 64.42 \%$; rural: $\mathrm{n}=48 ; 81.36 \%)$, living with the cared person and other family members (urban: $n=81 ; 49.69 \%$; rural: $n=24 ; 40.68 \%$ ), taking full-time care (urban: $n=98$; 60.12\%; rural: $n=41 ; 69.49 \%)$ and with the help of other people (urban: $n=114 ; 69.94 \%$; rural: $n=42 ; 71.19 \%$ ). The disparities in frequencies were found in the variables: education (urban: 7 to 13 years of study, $n=84 ; 51.53 \%$; rural: 0 to 6 years of study, $n=33 ; 55.93 \%$ ) and time of care (urban: 1 to 4 months, $n=62 ; 38.04 \%$; rural: $>8$ months, $n=32 ; 54.24 \%$ ), in which urban caregivers had more years of study and rural ones had longer time of care.

Among the results identified and presented in Table 1, it is generally noted that the strength of the correlations obtained was weak between the measures of caring ability and its dimensions with the factors of overburden, stress and the coping strategies used. When relating the measures of caring ability with stress, a negative and weak correlation was observed in the total care ability (total CAI-BR) $(\mathrm{r}=-0.165 ; \mathrm{p}=0.035)$ and in the dimensions of knowledge $(\mathrm{r}=-0.211 ; \mathrm{p}=0.007)$ and courage $(\mathrm{r}=-0.165 ; \mathrm{p}=0.035)$ in 
urban caregivers. These results show that, with the increase in the total care ability and the dimensions of knowledge and courage, there was a decrease in perceived stress among urban caregivers, or vice versa.

With regard to overburden and its factors, there is a negative correlation in the total CAI-BR $(r=-0.194 ; p=0.030)$ and in the courage dimension $(r=-0.206 ; p=0.021)$ with the PS factor. The IR factor shows a statistically significant and negative correlation in the knowledge dimension $(\mathrm{r}=-0.203$; $\mathrm{p}=0.034$ ). These results had weak intensity correlations, and may indicate that the greater the total care ability and courage, the less the overburden on the PS factor, and the greater the knowledge dimension, the less the overburden on the IR factor in caregivers.

In the analysis of the correlation measures of the caring ability and its dimensions, with coping strategies, a moderate, positive and statistically significant relationship was identified between the knowledge dimension and the coping strategies focused on the problem $(r=0.341 ; p<0.001)$. Thus, these results indicate that the greater the knowledge, the greater the use of strategies focused on the problem.
Regarding the perceived stress among rural caregivers, the results showed a statistically significant, negative and moderate relationship between the total CAI-BR $(r=-0.305$; $\mathrm{p}=0.019)$ and the knowledge dimension $(\mathrm{r}=-0.359 ; \mathrm{p}=0.005)$, demonstrating that the greater the total care ability and knowledge, the less the perception of stress among caregivers, and vice versa (Table 2).

When relating the measures of the caring ability and its dimensions with the overburden factors, there was a weak negative correlation in the knowledge dimension, and statistically significant with the IR factor $(r=-0.290 ; p=0.026)$, indicating that the greater the knowledge, the less the impact on the IR factor in rural caregivers.

When analyzing the measures of correlation of the caring ability and its dimensions with coping strategies, the results had a statistically significant, negative and moderate relationship in the maladaptive coping strategy focused on emotion, with the total CAI-BR $(r=-0.355 ; \mathrm{p}=0.008)$ and the knowledge dimension $(r=-0.334 ; p=0.013)$. These results indicate that the greater the total care ability and knowledge, the less the use of maladaptive coping strategies, focused on emotion among rural caregivers.

Table 1 - Correlation between measures of total care ability (Total CAI-BR) and its dimensions with the overburden, stress and coping of urban caregivers - Santa Maria, RS, Brazil, 2019.

\begin{tabular}{|c|c|c|c|c|c|c|c|c|c|}
\hline & & \multirow{2}{*}{$\begin{array}{c}\text { Perceived } \\
\text { Stress }\end{array}$} & \multicolumn{4}{|c|}{ Overburden } & \multicolumn{3}{|c|}{ Coping } \\
\hline & & & ICP & PS & ERC & IR & Problem & Adaptive & Maladaptive \\
\hline \multirow{2}{*}{ Total CAI-BR } & $r$ & -0.165 & -0.063 & -0.194 & -0.118 & -0.114 & 0.271 & 0.170 & -0.116 \\
\hline & $\mathrm{p}$-value & 0.035 & 0.455 & 0.030 & 0.135 & 0.236 & $\mathrm{p}<0.001$ & 0.031 & 0.141 \\
\hline \multirow{2}{*}{ Knowledge } & $r$ & -0.211 & -0.069 & -0.080 & -0.193 & -0.203 & 0.341 & 0.251 & -0.077 \\
\hline & $\mathrm{p}$-value & 0.007 & 0.412 & 0.370 & 0.104 & 0.034 & $\mathrm{p}<0.001$ & 0.001 & 0.328 \\
\hline \multirow{2}{*}{ Courage } & $r$ & -0.165 & -0.075 & -0.206 & -0.075 & -0.093 & 0.113 & 0.068 & -0.157 \\
\hline & $\mathrm{p}$-value & 0.035 & 0.375 & 0.021 & 0.344 & 0.333 & 0.152 & 0.389 & 0.045 \\
\hline \multirow{2}{*}{ Patience } & $r$ & 0.098 & 0.037 & -0.107 & 0.050 & 0.094 & 0.120 & 0.024 & 0.038 \\
\hline & $p$-value & 0.213 & 0.660 & 0.231 & 0.526 & 0.326 & 0.128 & 0.762 & 0.631 \\
\hline
\end{tabular}

$\mathrm{ICP}=\mathrm{Impact}$ on care provision; $\mathrm{PS}=$ Perception of self-efficacy; $E R C=$ Expectation regarding care; IR=Interpersonal relationship.

Table 2 - Correlation between the measures of total care ability (Total CAI-BR) and its dimensions with the overburden, stress and coping of rural caregivers - Santa Maria, RS, Brazil, 2019.

\begin{tabular}{|c|c|c|c|c|c|c|c|c|c|}
\hline & & \multirow{2}{*}{$\begin{array}{c}\text { Perceived } \\
\text { Stress }\end{array}$} & \multicolumn{4}{|c|}{ Overburden } & \multicolumn{3}{|c|}{ Coping } \\
\hline & & & ICP & PS & ERC & IR & Problem & Adaptive & Maladaptive \\
\hline \multirow{2}{*}{ Total CAI-BR } & $r$ & -0.305 & -0.177 & 0.050 & 0.027 & -0.241 & 0.081 & -0.053 & -0.355 \\
\hline & $\mathrm{p}$-value & 0.019 & 0.181 & 0.706 & 0.837 & 0.067 & 0.557 & 0.699 & 0.008 \\
\hline \multirow{2}{*}{ Knowledge } & $r$ & -0.359 & -0.167 & -0.092 & 0.020 & -0.290 & 0.049 & -0.128 & -0.334 \\
\hline & $\mathrm{p}$-value & 0.005 & 0.207 & 0.491 & 0.882 & 0.026 & 0.721 & 0.354 & 0.013 \\
\hline \multirow{2}{*}{ Courage } & $r$ & -0.148 & -0.013 & 0.205 & 0.072 & -0.139 & 0.167 & 0.011 & -0.201 \\
\hline & $\mathrm{p}$-value & 0.262 & 0.919 & 0.120 & 0.589 & 0.311 & 0.225 & 0.933 & 0.144 \\
\hline \multirow{2}{*}{ Patience } & $r$ & -0.058 & -0.110 & -0.112 & 0.039 & -0.051 & 0.063 & -0.010 & -0.113 \\
\hline & $\mathrm{p}$-value & 0.663 & 0.406 & 0.397 & 0.767 & 0.701 & 0.649 & 0.941 & 0.415 \\
\hline
\end{tabular}

$\mathrm{ICP}=$ Impact on care provision; $\mathrm{PS}=$ Perception of self-efficacy; $\mathrm{ERC}=$ Expectation regarding care; IR=Interpersonal relationship. 


\section{DISCUSSION}

The results of this study show similarity in the characterization of caregivers, in most of the variables analyzed, when comparing the urban and rural context. Thus, there is the reaffirmation that women have been the main provider of care, in line with the literature ${ }^{(21-22)}$, reflecting the important social role that women play in society, both at work and in caring for the home and family members ${ }^{(22)}$.

Regarding family income, most urban and rural caregivers reported receiving up to three minimum wages. This income may have been influenced by the removal from the labor market, in favor of the role of full-time caregiver, as identified in other studies ${ }^{(22)}$. In addition, it may reflect the reality of the Brazilian population ${ }^{(21)}$.

Receiving assistance from other people to perform daily life tasks and to care for the sick family member, a characteristic mentioned by urban and rural caregivers, can favor and strengthen the ability of caregivers to care, due to the fact that they have people to count on when they need support. Therefore, a study that compared urban and rural family caregivers identified that urban caregivers rely on the help of friends and other people, while the source of assistance for rural caregivers is usually centered on the family ${ }^{(23)}$.

Regarding the differences between the characteristics of urban and rural caregivers, it is evident that urban caregivers had more years of study while rural caregivers care for a longer period of time for their relative undergoing cancer treatment. The higher level of education among urban caregivers is a favorable factor for these individuals to have a positive view of care, having a better mental health ${ }^{(10)}$. On the other hand, the low level of education can result in caregiver overburden, as this reality, in addition to limiting insertion in the labor market and the prospects of meaning the care provided, circumscribes a condition in which they tend to dedicate to household activities ${ }^{(24)}$ and full-time care. In addition, being in the role of caregiver for a long period predisposes to engage in care with greater consistency ${ }^{(11,24)}$, which favors the development of caring abilities, although it can also become a factor that generates overburden by not seeing the possibility of changes in this scenario.

When comparing the relationship between the caring ability and its dimensions with the stress of caregivers, it was found that in rural caregivers the correlation was stronger in the total care ability and in the knowledge dimension than in urban caregivers. Thus, in the rural context stress can be developed due to the need to deal with external factors such as dependence of the family member and the demands for care in daily activities, which also includes the specific tasks of those who live in the rural environment, or in the presence of internal factors such as feelings of anxiety and insecurity ${ }^{(8,10)}$. The perceived stress can have a negative impact on the caregivers' ability to understand the needs of the dependent person, affecting their knowledge about the other person and about themselves, which can influence the total care ability $^{(5)}$. Comparative studies on stress in the urban and rural context with caregivers of people with chronic diseases showed that rural caregivers are more involved in care, accepting changes in their daily lives. However, urban caregivers had a more positive view of the responsibility to care, showing better mental health in the caregiver task ${ }^{(8-10)}$.

When comparing the results of the correlations between the overburden with the caring ability, a similarity was identified in the relationship between the knowledge dimension and the interpersonal relationship factor of the caregiver with the person cared for, both in urban and rural caregivers, noting that the greater the knowledge, the less the interpersonal impact resulting from the relationship of care provision. Still, there was a statistically significant correlation between the total care ability and courage with the perception of selfefficacy factor in urban caregivers, denoting that the greater the total care ability and courage, the less the impact on the perception of this factor, which is related to the caregivers' opinion regarding their caregiving performance.

So, knowing other people's need and the ability to care contributes to improving the interpersonal relationship of the caregiver with the individual being cared for ${ }^{(5,21)}$, positively influencing the caring ability, regardless of the context. In urban caregivers, the influence on the perception of selfefficacy, that is, the caregivers' opinion regarding their care performance, can interfere with the total care ability and courage, causing feelings of dissatisfaction in their care practice. Thus, a study that compared the experiences of urban family caregivers with rural ones showed that urban caregivers had more feelings of dissatisfaction in the responsibility to care, seen as an obligation to be fulfilled, limiting their personal space and independence ${ }^{(8)}$.

Regarding the results of the coping strategies identified in this study, differences were found in the correlation between urban and rural caregivers. Therefore, it was found that urban caregivers pointed out that the greater the knowledge, the greater the use of strategies focused on the problem. So, the caregiver makes a positive reassessment of the situation experienced at the moment, in which cognitive strategies are used to manage the feeling of the stressful moment ${ }^{(19)}$. Thus, the individual initiates an action, thinking about how to face the stressor, when seeking instrumental support in the form of information or advice from other people and also emotional support ${ }^{(17-19)}$.

Among rural caregivers it is evident that the lower the impact of maladaptive coping, that is, the use of denial strategies in an attempt to reject the stressful reality, blaming themselves, criticizing or failing to strive to face the stressor, the greater the total care ability and knowledge. However, it is observed that the type of strategy used by the caregiver can influence their total care ability and knowledge, both in urban and rural settings, which presupposes that the caregiver, regardless of the context, strives to manage stress ${ }^{(17-19)}$ and understand their needs and those of the person being cared for, leading to the development of greater care and knowledge abilities.

The evidence from this study contributes to the knowledge related to the caring ability, overburden, stress and coping strategies of urban and rural family caregivers. In addition, they can sensitize and encourage health professionals, especially nurses, to plan and implement actions that guide, instrumentalize, encourage, value and promote 
caregiver support and self-care, considering the particularities of the context in which they live. These actions have the potential to minimize overburden and stress, favoring the use of strategies focused on the problem, so that the situation experienced with sickness by cancer does not interfere with the caring ability.

The limitations of this study are related to the crosssectional design and the temporality bias, which makes the causal relationship of the investigated events unfeasible, as well as the delimitation of family caregivers linked to a public oncology specialized care service, which restricts the generalization of results. It is also noteworthy the lack of Brazilian studies that compare the caring abilities of urban and rural caregivers, which makes it difficult to discuss the results.

\section{CONCLUSION}

In this study it was found that urban and rural family caregivers were predominantly female, aged 48 to 76 years old, with a partner, with an income up to three minimum wages, who lived with the person being cared for and other family members, were full time caregivers and had the help of other people. The differences between urban and rural caregivers were concentrated on education and care time.
Urban caregivers had more years of study, while rural ones had more time in the caregiver role.

It was evidenced that the strength of the association between measures of the caring ability with stress was higher in rural caregivers, having a moderate, negative and statistically significant correlation in the total care ability and knowledge. It was found that, in urban caregivers, the association between the caring ability with overburden had a statistically significant, weak and negative correlation in the factor of perception of self-efficacy with the total care ability and courage and in the factor of interpersonal relationship with knowledge. In the association between caring ability and coping strategies, there was a statistically significant, moderate, and negative correlation in maladaptive coping with total care ability and knowledge among rural caregivers. In urban caregivers, the correlation was statistically significant, moderate and positive in coping focused on the problem with knowledge.

The findings of this study contribute for professionals who work in health services to mobilize information, guidance, and support strategies to strengthen and instrumentalize caregivers for care, to minimize overburden and stress. In

addition, it encourages new research to compare the context of other services, allowing these family caregivers to develop their caring abilities.

\section{RESUMO}

Objetivo: Correlacionar a habilidade de cuidado com a sobrecarga, o estresse e o coping de cuidadores familiares urbanos e rurais de pacientes em tratamento oncológico. Método: Estudo transversal, realizado em um hospital de referência no tratamento oncológico, com cuidadores do contexto urbano e rural que responderam aos instrumentos: questionário de caracterização sociodemográfica do cuidador e do cuidado prestado, escala de Estresse Percebido, escala Burden Interview e COPE Breve. Para a análise estatística, foi utilizado o teste de Correlação de Pearson, com nível de significância $\leq 5 \%$. Resultados: Participaram 163 cuidadores urbanos e 59 cuidadores rurais. Entre a habilidade de cuidado e o estresse, constatou-se correlação negativa e moderada nos cuidadores rurais. Na relação da habilidade de cuidado e a sobrecarga, verificou-se correlação estatisticamente significativa nos cuidadores urbanos no fator relação interpessoal e percepção de autoeficácia. Entre o coping e a habilidade de cuidado, identificou-se correlação positiva e moderada no coping focado no problema na dimensão conhecimento nos cuidadores urbanos. Conclusão: Cuidadores urbanos apresentaram maior intensidade de sobrecarga e coping focado no problema na relação com a habilidade de cuidado.

\section{DESCRITORES}

Cuidadores; Pacientes; Neoplasias; População Urbana; População Rural; Enfermagem Oncológica.

\section{RESUMEN}

Objetivo: Correlacionar la habilidad del cuidado con la sobrecarga, el estrés y el afrontamiento (coping) de familiares urbanos y rurales cuidadores de pacientes en tratamiento oncológico. Método: Se trata de un estudio transversal, realizado en un hospital referencia en tratamiento oncológico, con cuidadores de los medios urbano y rural que respondieron a los instrumentos: cuestionario de caracterización sociodemográfica del cuidador y de la atención prestada, escala de Estrés Percibido, escala de Entrevista de Carga y COPE 28. Para el análisis estadístico se utilizó la prueba de Correlación de Pearson, con nivel de significación $\leq 5 \%$. Resultados: Participaron 163 cuidadores urbanos y 59 cuidadores rurales. Entre la capacidad del cuidado y el estrés, se constató una correlación negativa y moderada en los cuidadores rurales. En la relación de la habilidad del cuidado y la sobrecarga, se comprobó una correlación estadísticamente significativa entre los cuidadores urbanos en el factor de la relación interpersonal y en la percepción de la autoeficacia. Entre el afrontamiento y la habilidad del cuidado, se identificó una correlación positiva y moderada en el afrontamiento, centrado en el problema de la dimensión de conocimientos de los cuidadores urbanos. Conclusión: Los cuidadores urbanos presentaron una mayor intensidad de sobrecarga y coping enfocado en el problema de la relación con la capacidad del cuidado.

\section{DESCRIPTORES}

Cuidadores; Pacientes; Neoplasias; Población Urbana; Población Rural; Enfermería Oncológica.

\section{REFERENCES}

1. Brasil. Ministério da Saúde; Instituto Nacional de Câncer Jose Alencar Gomes da Silva. Incidência de câncer no Brasil: estimativas 2016 [Internet]. Rio de Janeiro: INCA; 2015 [citado 2019 mar. 20]. Disponível em: https://www.inca.gov.br/campanhas/dia-nacional-decombate-ao-cancer/2015/estimativa-2016-incidencia-de-cancer-no-brasil 
2. Delalibera M, Barbosa A, Leal I. Circunstâncias e consequências do cuidar: caracterização do cuidador familiar em cuidados paliativos. Ciênc Saúde Coletiva. 2018;23(4):1105-17. doi: https://doi.org/10.1590/1413-81232018234.12902016

3. Fernandes CS, Angelo M. Family caregivers: what do they need? An integrative review. Rev Esc Enferm USP. 2016;50(4):672-8. doi: http:// dx.doi.org/10.1590/S0080-623420160000500019

4. Eterovic Díaz C, Mendoza Parra S, Sáez Carrilo K. Habilidad de cuidado y nivel de sobrecarga em cuidadoras/es informales de personas dependientes. Enferm Glob. 2015;14(2):235-48. doi: https://doi.org/10.6018/eglobal.14.2.198121

5. Nkongho N. The caring ability inventory. In: Watson J. Assessing and measuring caring in nursing. New York: Spriger; 2009.

6. Cantillo-Medina CP, Ramírez-Perdomo CA, Perdomo-Romero AY. Habilidad de cuidado en cuidadores familiares de personas con enfermedad crónica y sobrecarga percibida. Cienc Enferm. 2018;24:16. doi: http://dx.doi.org/10.4067/s0717-95532018000100216

7. Pompeo DA, Carvalho A, Olive AM, Souza MGG, Galera SAF. Strategies for coping with family members of patients with mental disorders. Rev Latino Am Enfermagem. 2016;24:e2799. doi: http://dx.doi.org/10.1590/1518-8345.1311.2799

8. Ehrlich K, Emami A, Heikkilä K. The relationship between geographical and social space and approaches to care among rural and urban caregivers caring for a family member with dementia: a qualitative study. Int J Qual Stud Health Well Being. 2017;12(1):1275107. doi: http://dx.doi.org/10.1080/17482631.2016.1275107

9. Brazil K, Kaasalainen S, Williams A, Dumont S. A comparison of support needs between rural and urban family caregivers providing palliative care. Am J Hosp Palliat Care. 2014;31(1):13-9. doi: https://doi.org/10.1177/1049909112474712

10. Tommis Y, Seddon D, Woods B, Robinson CA, Reeves C, Russell IT. Rural-urban differences in the effects on mental well-being of caring for people with stroke or dementia. Aging Ment Health. 2007;11(6):743-50. doi: http://dx.doi.org/10.1080/13607860701365972

11. Brazil K, Kaasalainen S, Williams A, Rodriguez C. Comparing the experiences of rural and urban family caregivers of the terminally ill. Rural Remote Health. 2014;13(1):2250.

12. Minosso, JSM, Amendola F, Alvarenga MRM, Oliveira MAC. Validação, no Brasil, do Índice de Barthel em idosos atendidos em ambulatórios. Acta Paul Enferm. 2010;23(2):218-23. doi: http://dx.doi.org/10.1590/S0103-21002010000200011

13. Rosanelli CL, Silva LM, Gutiérrez MGR. Cross-cultural adaptation of the Caring Ability Inventory to Portuguese. Acta Paul Enferm. 2016;29(3):347-54. doi:10.1590/1982-0194201600048

14. Scazufca M. Brazilian version of the Burden Interview Scale for the assessment of care in carers of people with mental illnesses. Rev Bras Psiquiatr. 2002;24(1):1217. doi: http://dx.doi.org/10.1590/S1516-44462002000100006

15. Luzardo AR, Gorini MIPC, Silva APSS. Características de idosos com doença de Alzheimer e seus cuidadores: uma série de casos em um serviço de Neurogeriatria. Texto Contexto Enferm. 2006;15(4):587-94. doi: http://dx.doi.org/10.1590/S0104-07072006000400006

16. Sequeira CAC. Adaptação e validação da Escala de Sobrecarga do Cuidador do Zarit. Rev Referência. 2010;2(12):9-16.

17. Cohen S, Kamarck T, Mermelstein R. A global measure of perceived stress. J Health Soc Behav. 1983;24(4):385-96.

18. Luft CDB, Sanches SO, Mazo GZ, Andrade A. Versão brasileira da Escala de Estresse Percebido: tradução e validação para idosos. Rev Saúde Pública. 2007;41(4):606-15. doi: http://dx.doi.org/10.1590/S0034-89102007000400015

19. Brasileiro SV. Adaptação Transcultural e Propriedades Psicométricas do COPE Breve em uma Amostra Brasileira [dissertação]. Goiânia: Universidade Federal de Goiás; 2012.

20. Ajzen I, Fishbein M. Understanding attitudes and predicting social behavior. New Jersey: Prentice-Hall; 1980.

21. Coppetti LC, Girardon-Perlini NMO, Andolhe R, Gutiérrez MGR, Dapper SN, Siqueira FD. Caring ability of family caregivers of patients on cancer treatment: associated factors. Rev Latino Am Enfermagem. 2018;26:e3048. doi: http://dx.doi.org/10.1590/1518-8345.2824.3048

22. Bierhals CCBK, Santos NO, Fengler FL, Raubustt KD, Forbes DA, Paskulin LMG. Needs of family caregivers in home care for older adults. Rev Latino Am Enfermagem. 2017;25:e2870. doi: http://dx.doi.org/10.1590/1518-8345.1511.2870

23. Mitchell LA, Hirdes J, Poss JW, Slegers-Boyd C, Caldarelli H, Martin L. Informal caregivers of clients with neurological conditions: profiles, patterns and risk factors for distress from a home care prevalence study. BMC Health Serv Res. 2015;15:350. doi: http://dx.doi.org/10.1186/ s12913-015-1010-1

24. Gratão ACM, Talmelli LFS, Figueiredo LC, Rosset I, Freitas CP, Rodrigues RAP. Functional dependency of older individuals and caregiver burden. Rev Esc Enferm USP. 2013;47(1):137-44. doi: http://dx.doi.org/10.1590/S0080-62342013000100017 